\title{
Carbon dioxide adsorption of diallylamine-modified natural rubber with modified silica particles
}

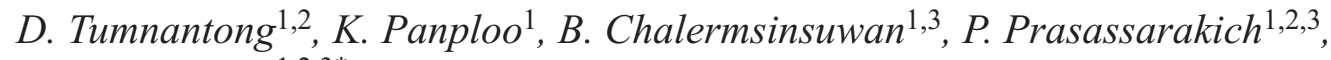 \\ S. Poompradub ${ }^{1,2,3^{*}}$ \\ ${ }^{1}$ Department of Chemical Technology, Faculty of Science, Chulalongkorn University, 10330 Bangkok, Thailand \\ ${ }^{2}$ Green Materials for Industrial Application Research Unit, Faculty of Science, Chulalongkorn University, \\ 10330 Bangkok, Thailand \\ ${ }^{3}$ Center of Excellence on Petrochemical and Materials Technology, Chulalongkorn University, 10330 Bangkok, Thailand
}

Received 20 February 2021; accepted in revised form 4 May 2021

\begin{abstract}
In this study, modified natural rubber (MNR) was used as a solid adsorbent for carbon dioxide $\left(\mathrm{CO}_{2}\right)$ capture. The chemical structure of the NR latex was modified by diallylamine. Moreover, the silica particles were modified by (3-aminopropyl)trimethoxysilane, $N$-[(3-trimethoxysilyl)propyl]ethylenediamine, or $N$-[(3-trimethoxysilyl)propyl]diethylenetriamine (mono-, di- and tri-amines) to improve the $\mathrm{CO}_{2}$ capture ability of the $\mathrm{MNR}$. The $\mathrm{CO}_{2}$ adsorption capacity of the MNR foam composite was increased 3- to 5-fold after filling with unmodified or modified silica particles. The mechanism for $\mathrm{CO}_{2}$ adsorption of the MNR composite was a combination of physisorption and chemisorption. At $100^{\circ} \mathrm{C}$, the highest $\mathrm{CO}_{2}$ adsorption capacity of MNR foam composite $(10.35 \mathrm{mg} / \mathrm{g}$ of adsorbent) was obtained by adding tri-amine-modified silica particles. Finally, the MNR foam composite material could be regenerated process for more than $20 \mathrm{CO}_{2}$ adsorption cycles.
\end{abstract}

Keywords: polymer composites, polymer synthesis, rubber, modified silica, $\mathrm{CO}_{2}$ adsorption

\section{Introduction}

The current dramatic global climate change is mainly caused by the elevated concentration of atmospheric greenhouse gases, especially carbon dioxide $\left(\mathrm{CO}_{2}\right)$ [1]. The $\mathrm{CO}_{2}$ emission forecast from 2018 to 2025 [2] shows a rising concentration of $\mathrm{CO}_{2}$ in the environment, which is mainly derived from fossil fuel combustion for energy production and transportation. Adsorption processes are one of the $\mathrm{CO}_{2}$ capture technologies that can effectively reduce the net $\mathrm{CO}_{2}$ emission rate because of their low-energy requirement, cost-effective method, high $\mathrm{CO}_{2}$ adsorption capacity, easy regeneration, and can be applied over a wide temperature and pressure range $[3,4]$. High porosity materials, including zeolite $[5,6]$, activated carbon [7, 8], metal-organic frameworks [9], and silica $[10,11]$, have been used as $\mathrm{CO}_{2}$ adsorbents. Among the various adsorption materials, silica has been applied the most because of its high surface area, large pore size, and facile surface functionalization [12]. Moreover, incorporating amine species onto the silica surface for enhancing $\mathrm{CO}_{2}$ capture has also been employed due to the high reactivity and selectivity of amines [13].

Directly introducing tetraethylenepentamine (TEPA) into the mesoporous silica SBA-15 resulted in a high $\mathrm{CO}_{2}$ adsorption capacity of $173 \mathrm{mg} / \mathrm{g}$ of adsorbent [14]. In addition, a mesocellular silica foam material modified by polyethyleneimine (PEI) with the largest window size exhibited a $\mathrm{CO}_{2}$ adsorption capacity of $152 \mathrm{mg} / \mathrm{g}$ of adsorbent [15]. The TEPA-impregnated mesoporous silica also had an increased 
$\mathrm{CO}_{2}$ adsorption capacity [16]. Accordingly, the use of amine-modified silica to reduce $\mathrm{CO}_{2}$ emission has attracted attention.

Synthetic polymer foams, such as poly(ethylenevinyl acetate) [17], poly(ethylene-propylene-diene) [18], acrylonitrile-butadiene rubber [19], and polyurethane foam [20], have gained in interest due to their significant potential in many applications. However, their chemical toxicity and environmental safety are of concern. Therefore, natural rubber (NR) is an alternative to replace these synthetic polymers. NR has good abrasion resistance, but it has poor aging and weathering, which are undesirable properties. Thus, chemical modification of NR has become an important method to improve its otherwise inferior properties [21]. Some hydrophilic monomers have been used to modify the NR latex to improve the interaction between the hydrophilic fillers and the rubbery matrix [22]. Dimethylaminoethyl acrylate [23], dimethylaminoethyl methacrylate [23, 24], and diallylamine [25] have been grafted onto the NR particles. In previous work [26, 27], NR latex foam with aminemodified silica was successfully developed as a $\mathrm{CO}_{2}$ adsorbent material. NR compounded with modified silica particles was found to enhance the $\mathrm{CO}_{2}$ adsorption capacity. However, there has been no report on the $\mathrm{CO}_{2}$ capture in modified NR (MNR). Accordingly, in this study, amine functionalization was used to improve the $\mathrm{CO}_{2}$ adsorption capacity of NR.

The aim of this study was to modify NR using diallylamine as a $\mathrm{CO}_{2}$ sorbent material. To enhance the $\mathrm{CO}_{2}$ adsorption capacity, silica particles modified by (3-aminopropyl)trimethoxysilane (1NM), N-[(3trimethoxysilyl)propyl]ethylenediamine (2NM), or $\mathrm{N}$-[(3-trimethoxysilyl)propyl]diethylenetriamine (3NM) were filled in the MNR sorbent material. The functional groups on the MNR structure and on the modified silica surface were confirmed by Fouriertransform infrared spectroscopy (FT-IR). The morphology of the MNR foam composite was examined by scanning electron microscopy (SEM), and the

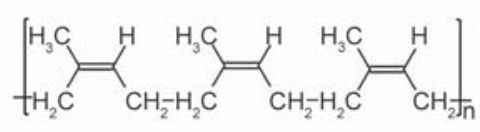

Natural rubber

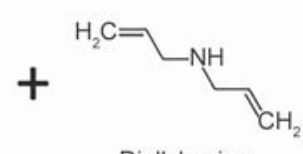

Diallylamine
$\mathrm{CO}_{2}$ adsorption capacity was investigated in a stainless steel reactor under ambient temperature and pressure with a mixed gas flow rate of $50 \mathrm{ml} / \mathrm{min}$. The effect of the temperature on the $\mathrm{CO}_{2}$ adsorption capacity, kinetic adsorption, and reusability of the MNR foam composite was evaluated. Finally, the mechanism of $\mathrm{CO}_{2}$ capture on the sorbent material was investigated.

\section{Experimental}

\subsection{Materials}

The NR latex with $60 \%$ by weight [wt $\%$ ] of dry rubber content was obtained from the Rubber Research Institute, Thailand. Tetraethyl orthosilicate (TEOS), diallylamine, $t$-butyl hydroperoxide, TEPA, and the three modifiers (1NM, 2NM, and 3NM) were purchased from Sigma-Aldrich, USA. Ammonium hydroxide $\left(\mathrm{NH}_{4} \mathrm{OH} ; 28.0 \%\right.$ purity) and ethanol (EtOH) were purchased from Qrec chemicals, Thailand. Acetone (AR grade) was purchased from Mermaid, Thailand, while $N, N$-dinitrosopentamenthylenetetramine (DNT) was supplied from Shaanxi Pioneer Biotech, China. Stearic acid, $N$-cyclohexyl-2-benzothiazole sulfernamide (CBS), sulfur, and zinc oxide were purchased from PAN Innovation, Thailand. All materials were used as received without further purification.

\subsection{Modification of NR latex}

The MNR was prepared as previously reported [25]. In brief, $100 \mathrm{~g}$ of NR latex was diluted with $0.26 \%$ $(\mathrm{w} / \mathrm{w}) \mathrm{NH}_{4} \mathrm{OH}(37 \mathrm{ml})$ in a closed glass reactor under a nitrogen $\left(\mathrm{N}_{2}\right)$ atmosphere. Then, $5 \mathrm{~g}$ of diallylamine in $110 \mathrm{ml}$ of $0.26 \%(\mathrm{w} / \mathrm{w}) \mathrm{NH}_{4} \mathrm{OH}$ was added to the reactor and mixed for 30 min under an $\mathrm{N}_{2}$ atmosphere at room temperature, followed by $1 \mathrm{~g}$ of $t$-butyl hydroperoxide (an initiator) and mixed for 15 min at room temperature. Finally, TEPA, as an activator, at $0.5 \mathrm{wt} \%$ of rubber was added, and the mixture was heated to $50^{\circ} \mathrm{C}$ and maintained with continuous stirring at $50^{\circ} \mathrm{C}$ for $24 \mathrm{~h}$. Finally, the MNR was coagulated with acetone and dried at $60^{\circ} \mathrm{C}$ in a

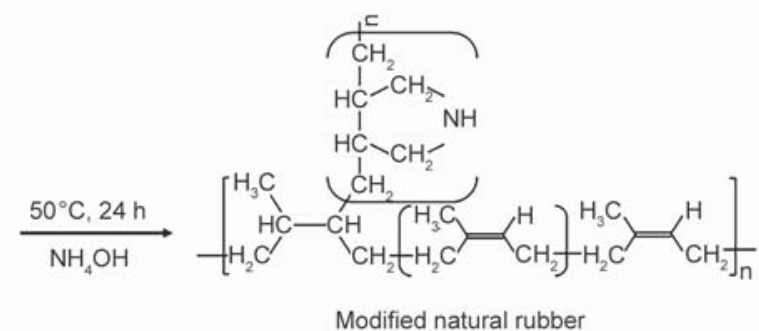

Figure 1. The modification of NR with diallylamine. 
vacuum oven. Figure 1 shows the modification of NR by diallylamine.

\subsection{Modification of silica particles}

The silica particles were modified via a sol-gel reaction by mixing two solutions at ambient temperature $[27,28]$. The first solution was a mixture of $3.0 \mathrm{ml}$ TEOS and $23.0 \mathrm{ml} \mathrm{EtOH}$, and the second solution was a mixture of $1.0 \mathrm{ml} 28 \%(\mathrm{w} / \mathrm{w}) \mathrm{NH}_{4} \mathrm{OH}$, $7.0 \mathrm{ml}$ deionized (DI) water, and $18.0 \mathrm{ml} \mathrm{EtOH}$. Then, the TEOS modifier ( 0.4 times by mole composition) was added into the mixed solution and continuously stirred at room temperature for $24 \mathrm{~h}$. For the unmodified silica particles, a similar procedure was performed only without adding the modifier. The silica particles with/without modifier were then separated by centrifugation, and the obtained silica particles were washed by DI water and dried until constant weight. The silica particles modified with 1NM, $2 \mathrm{NM}$, and $3 \mathrm{NM}$ were denoted as $1 \mathrm{NMSi}, 2 \mathrm{NMSi}$, and $3 \mathrm{NMSi}$ with the BET surface area of $72.6,1.8$, and $0.1 \mathrm{~m}^{2} / \mathrm{g}$, respectively.

\subsection{Preparation of MNR foam composites}

The formulation of the rubber compounding is listed in Table 1. All ingredients were mixed in a two-roll mill. The samples were then pressed by a compression mold at $100^{\circ} \mathrm{C}$ for $9 \mathrm{~min}$, and then the rubber foam sheet was heated in an oven at $140^{\circ} \mathrm{C}$ for $9 \mathrm{~min}$.

\subsection{Adsorption of $\mathrm{CO}_{2}$ by the MNR foam composites}

The NR or MNR adsorbent materials in a stainless steel reactor were treated under a vacuum condition at $60^{\circ} \mathrm{C}$ for $20 \mathrm{~min}$ to remove the adsorbed gas inside the adsorbent material and then cooled down to ambient temperature. Next, $\mathrm{N}_{2}$ was fed into the stainless

Table 1. Formulation of rubber compounding.

\begin{tabular}{|l|l|c|}
\hline \multicolumn{1}{|c|}{ Ingredient } & \multicolumn{1}{c|}{ Function } & $\begin{array}{c}\text { Weight } \\
\text { [phr] }\end{array}$ \\
\hline NR or MNR & Substrate & 100 \\
\hline Zinc oxide & Activator & 4 \\
\hline Stearic acid & Activator & 2 \\
\hline CBS $^{\mathrm{a}}$ & Accelerator & 3 \\
\hline DNT $^{\mathrm{b}}$ & Blowing agent & 2 \\
\hline Sulfur & Crosslinking agent & 3 \\
\hline Modified silica & Additive & 15 \\
\hline
\end{tabular}

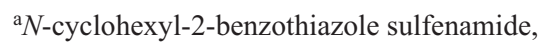

${ }^{\mathrm{b}} \mathrm{N}, \mathrm{N}$-dinitrosopentamenthylenetetramine steel reactor at a flow rate of $50 \mathrm{ml} / \mathrm{min}$ to expel $\mathrm{CO}_{2}$ from the system, followed by the mixed 12:88 (v/v) $\mathrm{CO}_{2}: \mathrm{N}_{2}$ at a flow rate of $50 \mathrm{ml} / \mathrm{min}$. This $\mathrm{CO}_{2}$ percentage is simulated flue gas from coal condition $\left(12-15\right.$ vol $\left.\% \mathrm{CO}_{2}\right)$ [29]. The $\mathrm{CO}_{2}$ concentration and gas temperature at the outlet were detected using a $\mathrm{CO}_{2}$ sensor.

\subsection{Characterization of the MNR and modified silica}

$\mathrm{N}_{2}$ adsorption-desorption isotherms were measured using Micromeritics ASAP-2020 at liquid $\mathrm{N}_{2}$ temperature $(77 \mathrm{~K})$. All samples were degassed at $150^{\circ} \mathrm{C}$ for $12 \mathrm{~h}$ under evacuation before analysis. The specific surface areas of modified silica particles were evaluated using the Brunauer-Emmett-Teller (BET) method.

The FT-IR spectra of MNR and modified silica particles were recorded at a resolution of $4 \mathrm{~cm}^{-1}$ using Nicolet Nexus 670, USA, operating in Attenuated Total Reflectance (ATR) mode with a diamond crystal having a refractive index of 2.4 at the incident angle $(\theta)$ of $45^{\circ}$.

The morphology of the NR and MNR filled with/ without modified silica particles was examined using SEM (JEPL, JSM-6480LV, Japan) at an acceleration voltage of $15 \mathrm{kV}$. The samples were first sputter coated with gold under a vacuum to make them electrically conductive.

\section{Results and discussion}

\subsection{Characterization of MNR}

Figure 2 shows the FT-IR spectra of diallylamine, NR, and MNR. The characteristic peaks of NR at 2961 and $2853 \mathrm{~cm}^{-1}$, corresponding to the asymmetric stretching of $-\mathrm{CH}_{3}$ and symmetric stretching of $-\mathrm{CH}_{2}$ [30], were evident. Bands at 1664, 1447, and $836 \mathrm{~cm}^{-1}$ were assigned to the $\mathrm{C}=\mathrm{C}$ stretching, $-\mathrm{CH}_{2}$ deformation, and $=\mathrm{CH}$ wagging bands of $\mathrm{NR}$, respectively [30]. The inclusion of diallylamine in the MNR increased the absorbance of the N-H stretching vibrations of amine at $3300 \mathrm{~cm}^{-1}$ [25], and the spectra at 1642 and $1544 \mathrm{~cm}^{-1}$ were assigned to the $\mathrm{N}-\mathrm{H}$ bending of amine [31]. However, the peaks at 993 and $915 \mathrm{~cm}^{-1}$ attributed to the $\mathrm{C}=\mathrm{C}$ bending of alkene in diallylamine disappeared because the alkene was changed to cycloalkane during the cyclopolymerization, as seen in Figure 1 [31]. Accordingly, the FT-IR results confirmed that the modification of NR was successfully obtained. 


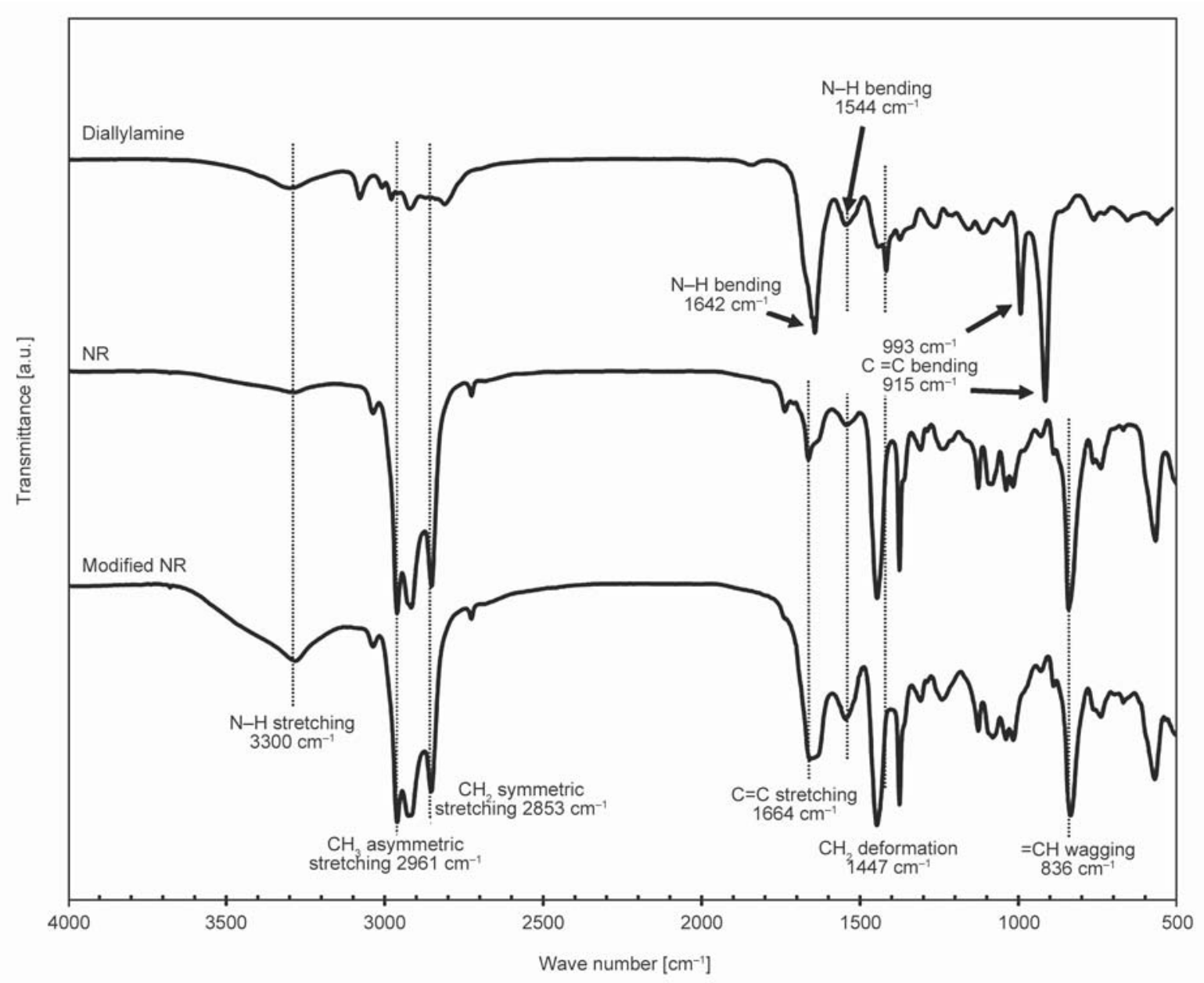

Figure 2. Representative FT-IR spectra of diallylamine, NR, and MNR.

\subsection{Characterization of the modified silica particles}

The FT-IR spectra of the unmodified and modified silica particles are shown in Figure 3. Unmodified silica particles showed strong signals at 1107 and $802 \mathrm{~cm}^{-1}$ associated with the asymmetric and symmetric stretching of $\mathrm{Si}-\mathrm{O}-\mathrm{Si}$, respectively $[32,33]$. The broad band at $948 \mathrm{~cm}^{-1}$ was due to the $\mathrm{Si}-\mathrm{O}$ inplane stretching vibration in the $\mathrm{Si}-\mathrm{OH}$ group [33], whilst the peaks at 3434 and $1630 \mathrm{~cm}^{-1}$ were attributed to the overlapped band of $\mathrm{O}-\mathrm{H}$ stretching of physically adsorbed water and the $\mathrm{SiO}-\mathrm{H}$ stretching of the silanol group $[32,33]$ and the $\mathrm{O}-\mathrm{H}$ deformation vibration of the adsorbed water [33], respectively. After modification, the intensity of the band at $948 \mathrm{~cm}^{-1}$ decreased, which indicated that some silanol groups were modified. Moreover, the FT-IR spectra of the modified silica particles showed the stretching and bending vibrations of the aliphatic amine $(\mathrm{N}-\mathrm{H})$ groups at about $3400-3300 \mathrm{~cm}^{-1}$ and 1630 $1680 \mathrm{~cm}^{-1}$, respectively [32]. Unfortunately, these were not evident following the modification of silica by these modifiers because their absorption peaks merged with the peaks of the $\mathrm{O}-\mathrm{H}$ deformation of water. Compared with the unmodified silica particles, some new peaks appeared at 2945 (asymmetric stretching vibrations), 2881 (symmetric stretching vibrations) and $1480 \mathrm{~cm}^{-1}$ (bending vibration) of $-\mathrm{CH}_{2}$ were observed for the amine-modified silica particles $[32,34]$. The presence of $-\mathrm{CH}_{2}$ vibrations on the modified silica particles indicated the successful grafting of the amino-organoalkoxyl groups (1NM, $2 \mathrm{NM}$, and $3 \mathrm{NM}$ ) on the surface of silica.

\subsection{Morphology of the MNR foam composite}

After successfully preparing either MNR or modified silica particles, the rubber composite material was prepared to obtain the adsorbent material for $\mathrm{CO}_{2}$ adsorption. Figure 4 shows SEM micrographs of the NR foam, MNR foam, and MNR foam composite filled with unmodified or modified silica particles. Both the NR and MNR foams showed a closedcell structure, but the cell size of the MNR foam was larger than that of the NR foam. This was because 


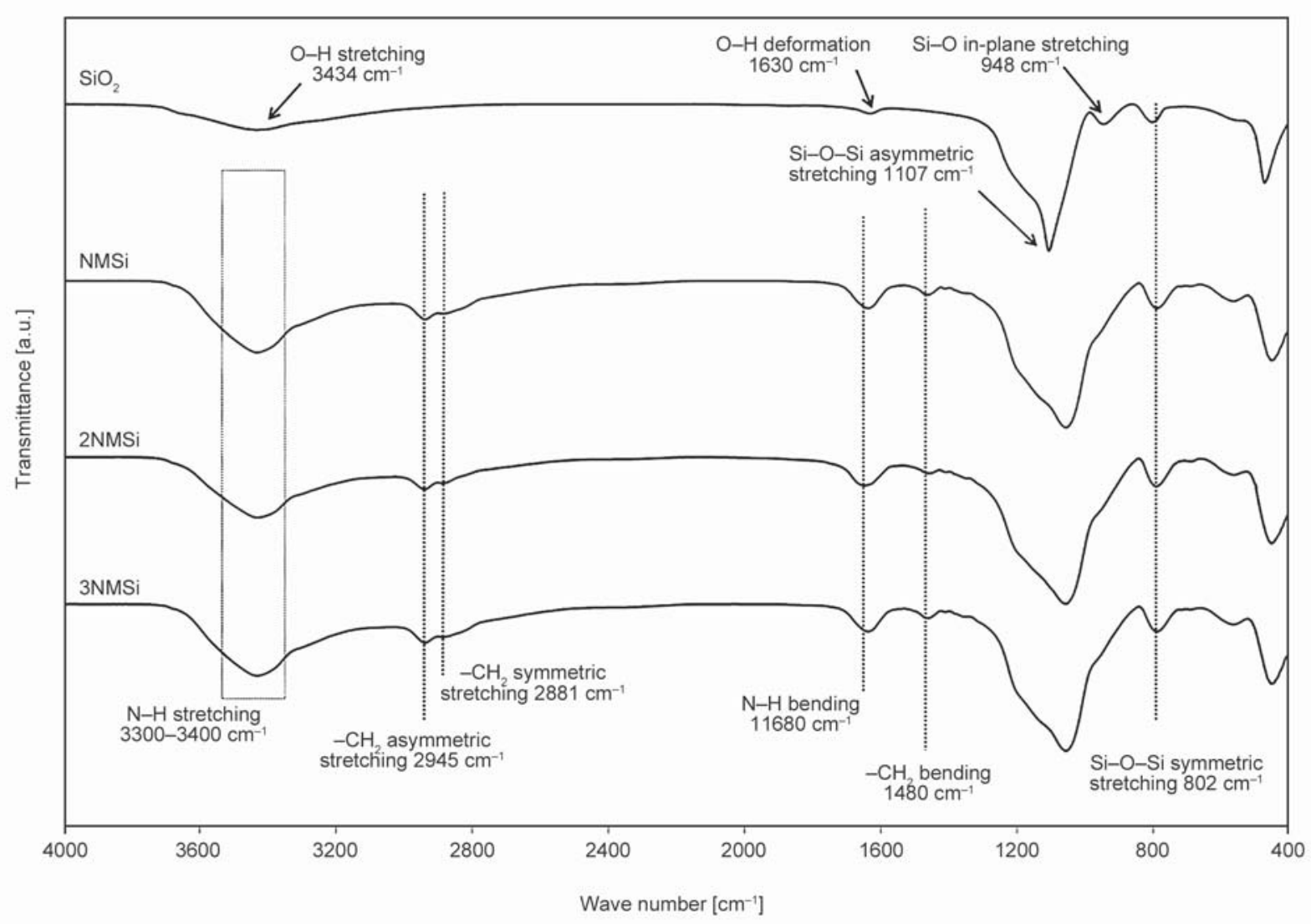

Figure 3. Representative FT-IR spectra of the unmodified and modified (1NM, 2NM, and 3NM) silica particles.
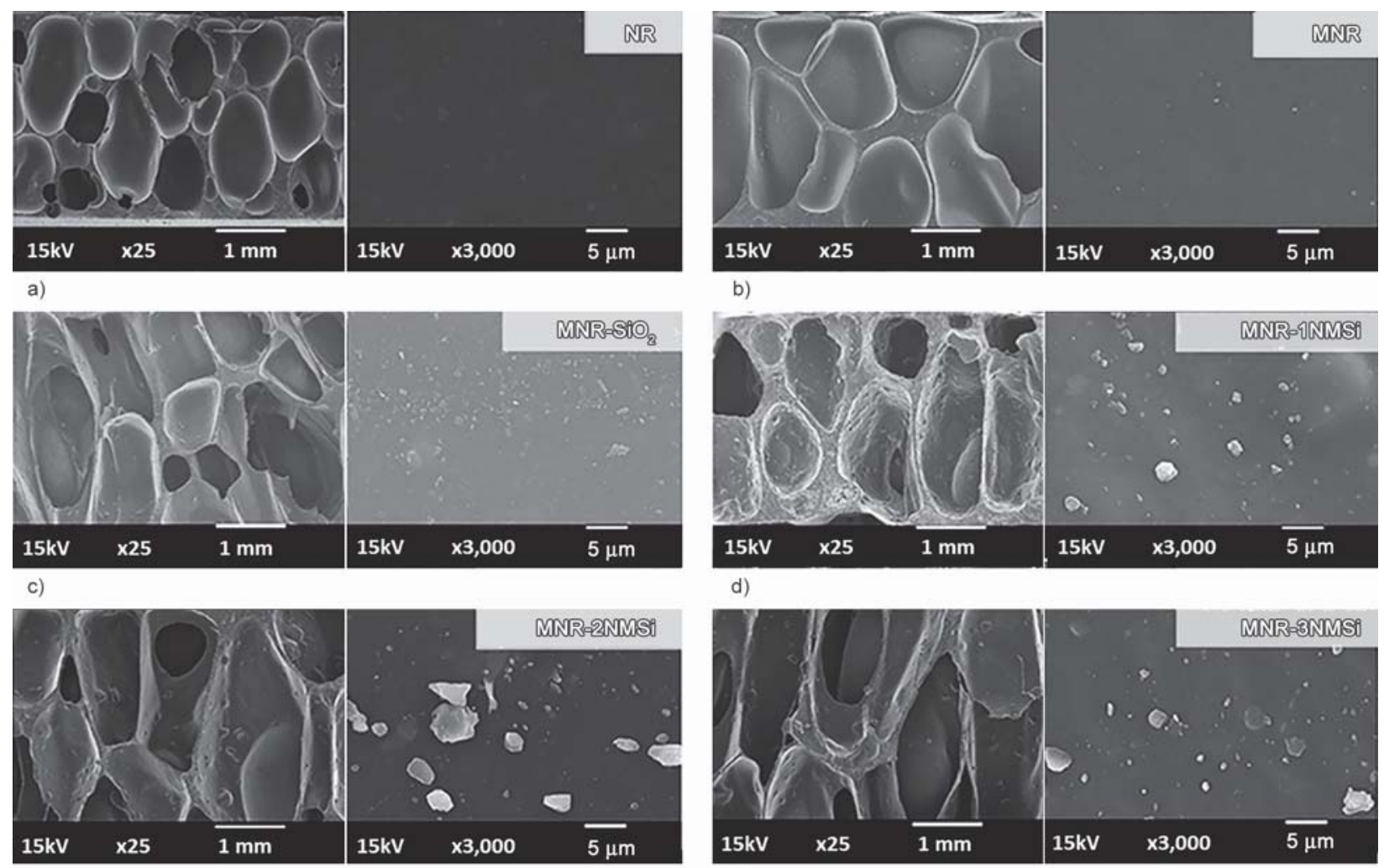

e)

f)

Figure 4. Representative SEM micrographs of the (a) NR, (b) MNR, and (c-f) MNR foam composite filled with (c) unmodified silica or silica modified with (d) 1NM, (e) 2NM, or (f) $3 \mathrm{NM}$. 
the increased size of the bulky chain of the MNR structure increased the space in the rubbery matrix, resulting in the foaming agent easily decomposing and forming the larger cell structure. After filling with the $\mathrm{SiO}_{2}$, the morphology of MNR foam composite was not significantly changed, but the unmodified silica particles showed a good distribution in the rubbery matrix while the modified silica particles tended to be aggregated due to the increased basicity of each modifier. Accordingly, the modifier acted as a catalyst to increase the rate of the sol-gel reaction, resulting in the aggregates or agglomerates of the modified silica particles.

\subsection{The $\mathrm{CO}_{2}$ adsorption capacity}

The $\mathrm{CO}_{2}$ adsorption capacity of the MNR foam composites was investigated at ambient temperature and pressure, and the results are summarized in Table 2. The adsorption capacity of the NR foam was $0.79 \mathrm{mg} / \mathrm{g}$ of adsorbent. At the same time, this was 1.6-fold higher for the MNR foam $(1.26 \mathrm{mg} / \mathrm{g}$ of adsorbent), which was because of the increased amine groups in the MNR structure that increased the $\mathrm{CO}_{2}$ selectivity. To further improve the $\mathrm{CO}_{2}$ adsorption capacity of the MNR foam, unmodified or modified silica particles were then filled in the MNR foam and the effect of the three amine types (mono-, di-, and tri-amine, or $1 \mathrm{MN}, 2 \mathrm{MN}$, and $3 \mathrm{MN}$, respectively) on the surface of the modified silica particles was evaluated. The $\mathrm{CO}_{2}$ adsorption capacity of the MNR foam composite was increased from 3- to 5-fold after filling with unmodified to $3 \mathrm{MN}$-modified silica particles (Table 2), owing to the increased surface area and $\mathrm{CO}_{2}$ selectivity to adsorb $\mathrm{CO}_{2}$. Moreover, the highest adsorption capacity was achieved using the

Table 2. $\mathrm{CO}_{2}$ adsorption capacity of MNR foam composite material.

\begin{tabular}{|c|c|}
\hline Sample code & $\begin{array}{l}\mathrm{CO}_{2} \text { adsorption capacity } \\
\text { [mg/g of adsorbent] }\end{array}$ \\
\hline NR & 0.79 \\
\hline MNR & 1.26 \\
\hline $\mathrm{MNR} \mathrm{SiO}_{2}{ }^{\mathrm{a}}$ & 4.29 \\
\hline MNR-1NMSi ${ }^{b}$ & 5.06 \\
\hline MNR-2NMSic & 6.05 \\
\hline MNR-3NMSi ${ }^{\mathrm{d}}$ & 6.11 \\
\hline
\end{tabular}

\footnotetext{
${ }^{\mathrm{a}-\mathrm{d} M N R}$ filled with

${ }^{a}$ unmodified silica particles, and silica particles modified with

b3-aminopropyltrimethoxysilane (1NM),

${ }^{\mathrm{c}} N$-[(3-trimethoxysilyl)propyl]ethylenediamine (2NM),

${ }^{\mathrm{d}} \mathrm{N}$-[(3-trimethoxysilyl)propyl]diethylenetriamine (3NM).
}

tri-amine (3MN), which simply reflected the increasing amount of amine units per silane (tri- $>$ di- $>$ mono-). In contrast, in a previous study, the use of the mono-amine showed the highest $\mathrm{CO}_{2}$ adsorption capacity [27]. This might reflect that the long chain length of the di- or tri-amine silanes could tangle with the NR chains and potentially block many of the secondary amine locations on its tether and so inhibit access for $\mathrm{CO}_{2}$ capture.

\subsection{Kinetics of the $\mathrm{CO}_{2}$ adsorption on the MNR foam composite}

The behavior of $\mathrm{CO}_{2}$ adsorption process for each adsorbent was compared to the predictions of three models of adsorption kinetics: pseudo-first order, pseudo-second order, and Avrami's models, shown in Equations (1)-(3), respectively [34, 35]:

Pseudo-first order: $\quad q_{\mathrm{t}}=q_{\mathrm{e}}\left[1-\exp \left(-k_{1} t\right)\right]$

Pseudo-second order: $q_{\mathrm{t}}=\frac{k_{2} q_{\mathrm{e}}^{2} t}{1+k_{2} q_{\mathrm{e}} t}$

$$
\text { Avrami's: } \quad q_{\mathrm{t}}=q_{\mathrm{e}}\left[1-\exp \left(-k_{\mathrm{A}} t\right)^{\mathrm{n}_{\mathrm{A}}}\right](3)
$$

where $k_{1}\left[\mathrm{~min}^{-1}\right], k_{2}[\mathrm{~g} /(\mathrm{mmol} \cdot \mathrm{min})]$, and $k_{\mathrm{A}}\left[\mathrm{min}^{-1}\right]$ are the respective rate constants, $q_{\mathrm{e}}[\mathrm{mmol} / \mathrm{g}]$ is the adsorption capacity, $q_{\mathrm{t}}[\mathrm{mmol} / \mathrm{g}]$ is the amount of gas adsorbed in a specific time $t$ [min], and $n_{\mathrm{A}}$ is the order of the kinetic equation.

The kinetic parameters of these models, along with the coefficient of correlation $\left(R^{2}\right)$ and rate constants, were estimated and are summarized in Table 3. The Avrami's kinetic model fitted well with the adsorption

Table 3. Linear regression parameters for the kinetic data of $\mathrm{CO}_{2}$ adsorption on the MNR foam composites.

\begin{tabular}{|l|l|c|c|c|}
\hline \multicolumn{2}{|c|}{ Model parameters } & MNR & MNR-SiO $^{\mathbf{a}}$ & MNR-3NMSi $^{\mathbf{a}}$ \\
\hline \multirow{2}{*}{$\begin{array}{l}\text { Pseudo-first } \\
\text { order }\end{array}$} & $k_{1}$ & 0.0103 & 0.0055 & 0.0072 \\
\cline { 2 - 5 } & $R^{2}$ & 0.9266 & 0.9336 & 0.9871 \\
\hline \multirow{2}{*}{$\begin{array}{l}\text { Pseudo-second } \\
\text { order }\end{array}$} & $k_{2}$ & 0.9018 & 0.4333 & 0.2488 \\
\cline { 2 - 5 } & $R^{2}$ & 0.5249 & 0.8791 & 0.7927 \\
\hline \multirow{3}{*}{ Avrami } & $k_{\mathrm{A}}$ & 0.0069 & 0.0061 & 0.0058 \\
\cline { 2 - 5 } & $R^{2}$ & 0.9896 & 0.9608 & 0.9985 \\
\cline { 2 - 5 } & $n_{\mathrm{A}}$ & 1.2469 & 1.0535 & 1.1351 \\
\hline
\end{tabular}

${ }^{a}$ MNR foam filled with unmodified silica particles or silica particles modified with $N$-[(3-trimethoxysilyl)propyl]diethylenetriamine (3NM). 

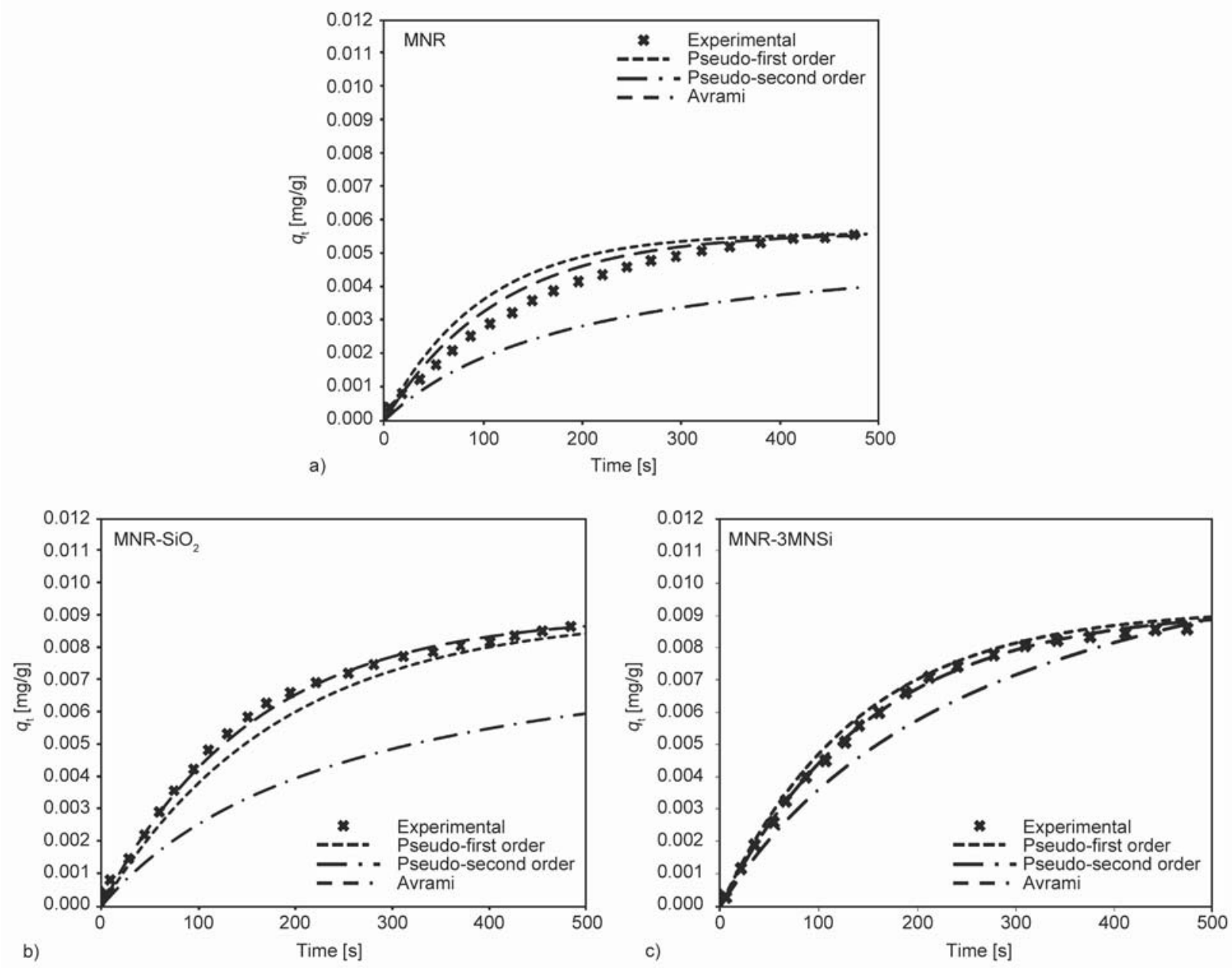

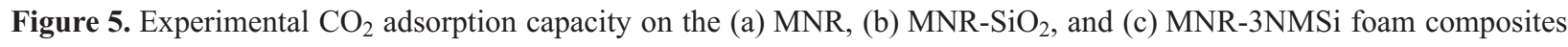
and the corresponding fit to the different kinetic models.

kinetics data with a high $R^{2}(>0.95)$ value, which was consistent with the fitting results (Figure 5). Thus, the $\mathrm{CO}_{2}$ adsorption mechanism of the MNR foam composite was the combination of physisorption and chemisorption (Figure 6). The $n_{\mathrm{A}}$ of the MNR foam composites was in the range between 1.0535 and 1.2469 , which supported a complex reaction mechanism $[27,36]$. The physisorption process occurred at the pores of MNR foam or modified silica particles, while the chemisorption occurred from the reaction between $\mathrm{CO}_{2}$ molecules and amine groups at the MNR structure or on the surface of the modified silica particle surface.

\subsection{Effect of temperature on the $\mathrm{CO}_{2}$ adsorption capacity of the MNR foam composites}

The $\mathrm{CO}_{2}$ adsorption capacity of the MNR foam composites was investigated at various temperatures (ambient temperature, 55,70 , and $100^{\circ} \mathrm{C}$ ), and the results are summarized in Figure 7. The $\mathrm{CO}_{2}$ adsorption capacity of the MNR foam tended to increase with increasing temperatures up to $70^{\circ} \mathrm{C}$ and then decreased when the temperature was further increased to $100^{\circ} \mathrm{C}$. This was because the structure of the MNR foam might shrink, and the rubber chains would then possibly block the amine groups on the structure. The rubber shrinkage during heating is due to the entropy change (from low to high), hence 'Thermoelastic behavior' [37, 38]. In contrast, the $\mathrm{CO}_{2}$ adsorption capacity of the MNR foam composites filled with silica and, especially, 3NMSi increased with increasing temperatures up to $100^{\circ} \mathrm{C}$. The addition of filler (silica or $3 \mathrm{NMSi}$ ) in the MNR foam decreased the volume in the composite, and the resulting structure could not shrink, and so the higher temperature increased the reaction rate. Moreover, the modifier chain on the surface of the modified silica particles became more flexible at a higher temperature, so the active site for $\mathrm{CO}_{2}$ capture was not hidden. 


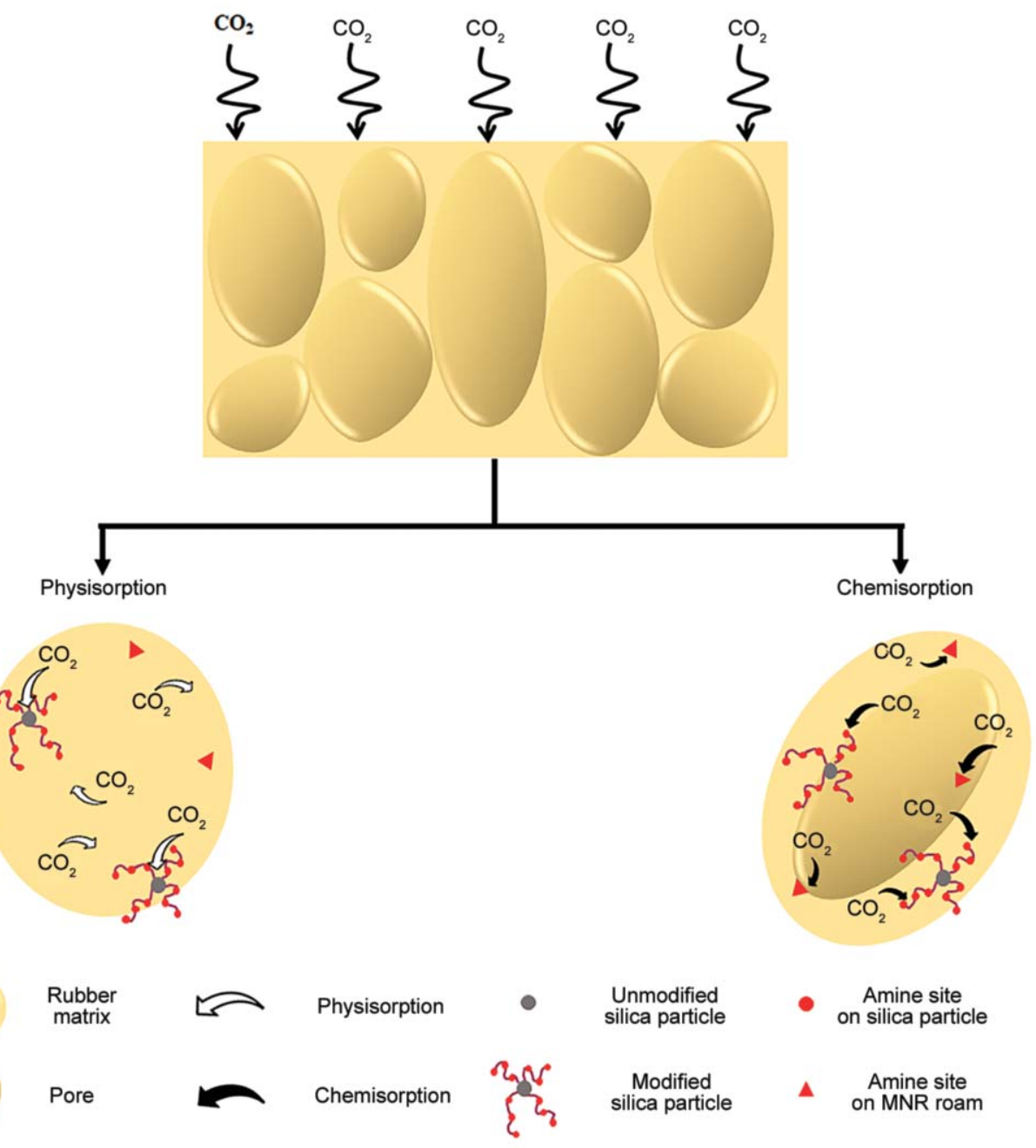

Figure 6. Schematic diagram showing the $\mathrm{CO}_{2}$ adsorption mechanism on the MNR foam composites.

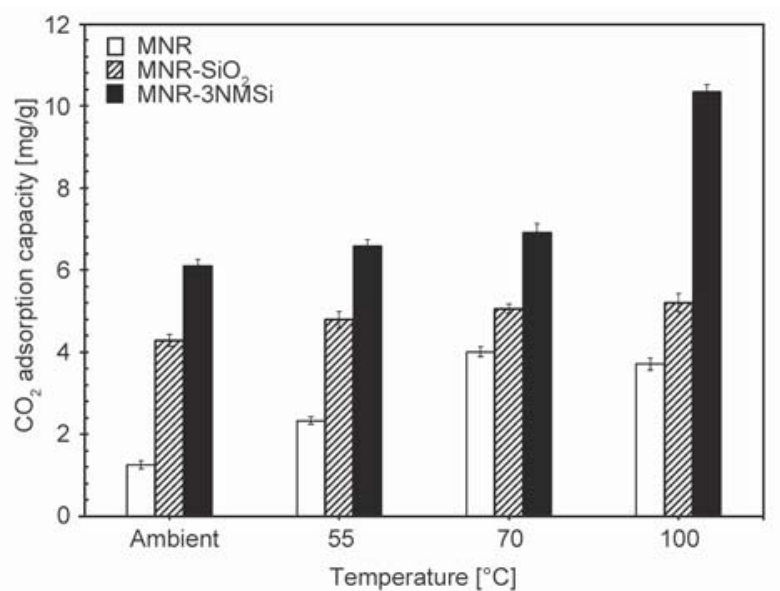

Figure 7. The $\mathrm{CO}_{2}$ adsorption capacity of the MNR and $\mathrm{MNR}-\mathrm{SiO}_{2}$ and MNR-3NMSi foam composites at different temperatures.

\subsection{Regeneration of the adsorbents}

Besides the adsorption behavior, the regeneration behavior is also important for use as an adsorbent material. Figure 8 shows the $\mathrm{CO}_{2}$ adsorption stability of NR, MNR, MNR-SiO , and MNR-3NMSi over

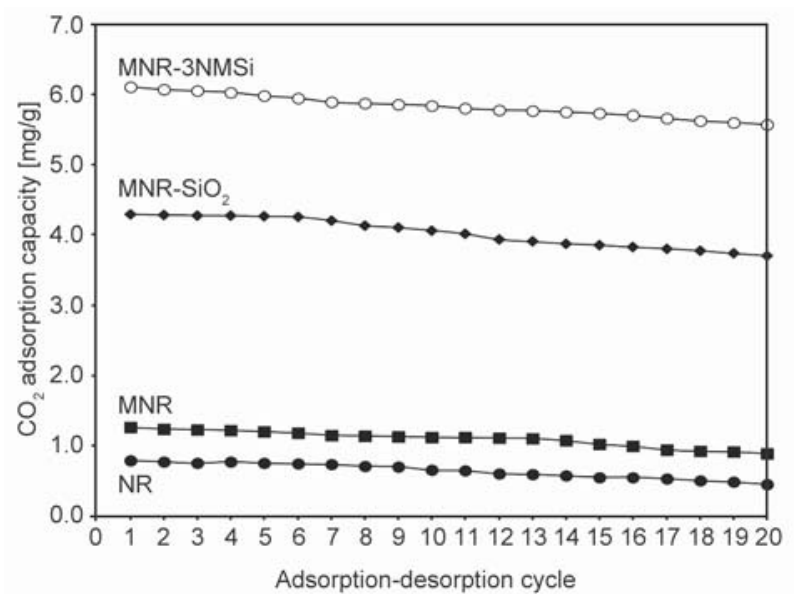

Figure 8. The cyclic $\mathrm{CO}_{2}$ adsorption capacity of the MNR foam composites.

20 successive adsorption-desorption cycles of adsorbing $12 \%(\mathrm{v} / \mathrm{v}) \mathrm{CO}_{2}$ at ambient temperature and regenerating the adsorbent material at $60^{\circ} \mathrm{C}$ under vacuum for 20 min under $\mathrm{N}_{2}$. For all materials, the $\mathrm{CO}_{2}$ adsorption capacity slightly decreased with each successive cycle due to decay of the material. 
However, after 20 adsorption-desorption cycles, only a maximum $8.3 \%$ (in the case of MNR-3NMSi) decreased $\mathrm{CO}_{2}$ adsorption capacity was observed compared to the fresh adsorbent material. Therefore, it was summarized that the adsorbent materials were stable and could be reused.

\section{Conclusions}

The MNR was successfully prepared by modification of NR with diallylamine. After curation, the $\mathrm{CO}_{2}$ adsorption capacity of the MNR foam $(1.26 \mathrm{mg} / \mathrm{g}$ of adsorbent) was 1.6-fold higher than that of the NR foam $(0.79 \mathrm{mg} / \mathrm{g}$ of adsorbent $)$ due to the presence of amine groups in MNR structure. The inclusion of amine-modified silica particles further enhanced the $\mathrm{CO}_{2}$ adsorption capacity of the MNR foam composites. In addition, the $\mathrm{CO}_{2}$ adsorption capacity of the MNR foam composite material increased depending on the amine type used to modify the silica particles in the order of tri- > di- > mono-amines. The kinetic adsorption of the MNR foam composite fitted well with Avrami's model. Increasing the temperature up to $100^{\circ} \mathrm{C}$ increased the $\mathrm{CO}_{2}$ adsorption capacity of the MNR foam composites, and the MNR foam composites showed high reusability for more than $20 \mathrm{cy}-$ cles with $<8 \%$ loss of $\mathrm{CO}_{2}$ adsorption. Accordingly, this kind of material could be used as a sorbent material to reduce $\mathrm{CO}_{2}$ greenhouse gas emissions into the atmosphere.

\section{Acknowledgements}

The authors acknowledge the Thailand Research Fund (Grant No. RSA6180030), Malaysia-Thailand Joint Authority (MTJA), Research Cess Fund, the Asahi Glass Foundation, the Center of Excellence on Petrochemical and Materials Technology and the Ratchadapisek Somphot Fund for Postdoctoral Fellowship, Chulalongkorn University.

\section{References}

[1] Abeydeera L. H. U.W., Mesthrige J. W., Samarasinghalage T. I.: Global research on carbon emissions: A scientometric review. Sustainability, 11, 3972/1-3972/25 (2019). https://doi.org/10.3390/su11143972

[2] Qiao W., Lu H., Zhou G., Azimi M., Yang Q., Tian W.: A hybrid algorithm for carbon dioxide emissions forecasting based on improved lion swarm optimizer. Journal of Cleaner Production, 244, 118612/1-118612/16 (2020).

https://doi.org/10.1016/j.jclepro.2019.118612
[3] Dissanayake P. D., You S., Igalavithana A. D., Xia Y., Bhatnagar A., Gupta S., Kua H. W., Kim S., Kwon J-H., Tsang D. C. W., Ok Y. S.: Biochar-based adsorbents for carbon dioxide capture: A critical review. Renewable and Sustainable Energy Reviews, 119, 109582/1109582/14 (2020).

https://doi.org/10.1016/j.rser.2019.109582

[4] Hussin F., Aroua M. K.: Recent trends in the development of adsorption technologies for carbon dioxide capture: A brief literature and patent reviews (2014-2018). Journal of Cleaner Production, 253, 119707/1-119707/25 (2020).

https://doi.org/10.1016/j.jclepro.2019.119707

[5] Megías-Sayago C., Bingre R., Huang L., Lutzweiler G., Wang Q., Louis B.: $\mathrm{CO}_{2}$ adsorption capacities in zeolites and layered double hydroxide materials. Frontiers in Chemistry, 7, 551/1-551/10 (2019).

https://doi.org/10.3389/fchem.2019.00551

[6] Murge P., Dinda S., Roy S.: Zeolite-based sorbent for $\mathrm{CO}_{2}$ capture: Preparation and performance evaluation. Langmuir, 35, 14751-14760 (2019). https://doi.org/10.1021/acs.langmuir.9b02259

[7] Botomé M. L., Poletto P., Junges J., Perondi D., Dettmer A., Godinho M.: Preparation and characterization of a metal-rich activated carbon from CCA-treated wood for $\mathrm{CO}_{2}$ capture. Chemical Engineering Journal, 321, 614-621 (2017). https://doi.org/10.1016/j.cej.2017.04.004

[8] Li M., Xiao R.: Preparation of a dual pore structure activated carbon from rice husk char as an adsorbent for $\mathrm{CO}_{2}$ capture. Fuel Processing Technology, 186, 35-39 (2019). https://doi.org/10.1016/j.fuproc.2018.12.015

[9] $\mathrm{Hu}$ Z., Wang Y., Shah B. B., Zhao D.: $\mathrm{CO}_{2}$ capture in metal-organic framework adsorbents: An engineering perspective. Advanced Sustainable Systems, 3, 1800080/1-1800080/21 (2019).

https://doi.org/10.1002/adsu.201800080

[10] Sanz-Pérez E. S., Dantas T. C. M., Arencibia A., Calleja G., Guedes A. P. M. A., Araujo A. S., Sanz R.: Reuse and recycling of amine-functionalized silica materials for $\mathrm{CO}_{2}$ adsorption. Chemical Engineering Journal, 308, 1021-1033 (2017). https://doi.org/10.1016/j.cej.2016.09.109

[11] Lee J. J., Yoo C-J., Chen C-H., Hayes S. E., Sievers C., Jones C. W.: Silica-supported sterically hindered amines for $\mathrm{CO}_{2}$ capture. Langmuir, 34, 12279-12292 (2018). https://doi.org/10.1021/acs.langmuir.8b02472

[12] Asefa T., Tao Z.: Mesoporous silica and organosilica materials - Review of their synthesis and organic functionalization. Canadian Journal of Chemistry, 90, 10151031 (2012).

https://doi.org/10.1139/v2012-094

[13] Chen C., Zhang S., Row K. H., Ahn W-S.: Amine-silica composites for $\mathrm{CO}_{2}$ capture: A short review. Journal of Energy Chemistry, 26, 868-880 (2017). https://doi.org/10.1016/j.jechem.2017.07.001 
[14] Yue M. B., Chun Y., Cao Y., Dong X., Zhu J. H.: $\mathrm{CO}_{2}$ capture by as-prepared SBA-15 with an occluded organic template. Advanced Functional Materials, 16, 1717-1722 (2006).

https://doi.org/10.1002/adfm.200600427

[15] Yan X., Zhang L., Zhang Y., Qiao K., Yan Z., Komarneni S.: Amine-modified mesocellular silica foams for $\mathrm{CO}_{2}$ capture. Chemical Engineering Journal, 168, 918-924 (2011).

https://doi.org/10.1016/j.cej.2011.01.066

[16] Fujiki J., Yamada H., Yogo K.: Enhanced adsorption of carbon dioxide on surface-modified mesoporous silicasupported tetraethylenepentamine: Role of surface chemical structure. Microporous and Mesoporous Materials, 215, 76-83 (2015).

https://doi.org/10.1016/j.micromeso.2015.05.037

[17] Sarver J. A., Sumey J. L., Williams M. L., Bishop J. P., Dean D. M., Kiran E.: Foaming of poly(ethylene-covinyl acetate) and poly(ethylene-co-vinyl acetate-cocarbon monoxide) and their blends with carbon dioxide. Journal of Applied Polymer Science, 135, 45841/145841/24 (2018).

https://doi.org/10.1002/app.45841

[18] Wang X., Wang Y., Ma L., Guo H., Yang C., Liu N., Wang J.: Design of ethylene-propylene-diene monomer foam and its double-layer composite for improving sound absorption properties via experimental method and theoretical verification. Polymer Engineering and Science, 60, 1877-1889 (2020).

https://doi.org/10.1002/pen.25424

[19] Han D-H., Choi M-C., Jeong J-H., Choi K-M., Kim HS.: Properties of acrylonitrile butadiene rubber (NBR)/ poly(lactic acid) (PLA) blends and their foams. Composite Interfaces, 23, 771-780 (2016).

https://doi.org/10.1080/09276440.2016.1170518

[20] Almeida M. L. B., Ayres E., Moura F. C. C., Oréfice R. L.: Polyurethane foams containing residues of petroleum industry catalysts as recoverable $\mathrm{pH}$-sensitive sorbents for aqueous pesticides. Journal of Hazardous Materials, 346, 285-295 (2018).

https://doi.org/10.1016/j.jhazmat.2017.12.033

[21] Phinyocheep P.: Chemical modification of natural rubber (NR) for improved performance. in 'Chemistry, manufacture and applications of natural rubber' (eds.: Kohjiya S., Ikeda Y.) Woodhead, London, 68-118 (2014). https://doi.org/10.1533/9780857096913.1.68

[22] Oliveira P. C., Guimarães A., Cavaillé J-Y., Chazeau L., Gilbert R. G., Santos A. M.: Poly(dimethylaminoethyl methacrylate) grafted natural rubber from seeded emulsion polymerization. Polymer, 46, 1105-1111 (2005). https://doi.org/10.1016/j.polymer.2004.11.048

[23] Kangwansupamonkon W., Gilbert R. G., Kiatkamjornwong S.: Modification of natural rubber by grafting with hydrophilic vinyl monomers. Macromolecular Chemistry and Physics, 206, 2450-2460 (2005).

https://doi.org/10.1002/macp.200500255
[24] Jayadevan J., Alex R., Gopalakrishnapanicker U.: Chemically modified natural rubber latex - poly(vinyl alcohol) blend membranes for organic dye release. Reactive and Functional Polymers, 112, 22-32 (2017). https://doi.org/10.1016/j.reactfunctpolym.2017.01.001

[25] Jong L.: Reinforcement effect of soy protein nanoparticles in amine-modified natural rubber latex. Industrial Crops and Products, 105, 53-62 (2017). https://doi.org/10.1016/j.indcrop.2017.05.007

[26] Panploo K., Chalermsinsuwan B., Poompradub S.: Natural rubber latex foam with particulate fillers for carbon dioxide adsorption and regeneration. RSC Advances, 9, 28916-28923 (2019).

https://doi.org/10.1039/C9RA06000F

[27] Panploo K., Chalermsinsuwan B., Poompradub S.: Effect of amine types and temperature of a natural rubber based composite material on the carbon dioxide capture. Chemical Engineering Journal, 402, 125332/1125332/9 (2020).

https://doi.org/10.1016/j.cej.2020.125332

[28] Theppradit T., Prasassarakich P., Poompradub S.: Surface modification of silica particles and its effects on cure and mechanical properties of the natural rubber composites. Materials Chemistry and Physics, 148, 940-948 (2014).

https://doi.org/10.1016/j.matchemphys.2014.09.003

[29] Songolzadeh M., Soleimani M., Takht Ravanchi M., Songolzadeh R.: Carbon dioxide separation from flue gases: A technological review emphasizing reduction in greenhouse gas emissions. The Scientific World Journal, 2014, 828131/1-828131/34 (2014).

https://doi.org/10.1155/2014/828131

[30] Ibrahim S., Daik R., Abdullah I.: Functionalization of liquid natural rubber via oxidative degradation of natural rubber. Polymers, 6, 2928-2941 (2014).

https://doi.org/10.3390/polym6122928

[31] Kadem K. J.: Cyclopolymerization of diallylamine and its condensation with carboxylic drugs. International Journal of Chemical Sciences, 13, 725-736 (2015).

[32] Lu H-T.: Synthesis and characterization of amino-functionalized silica nanoparticles. Colloid Journal, 75, 311-318 (2013).

https://doi.org/10.1134/S1061933X13030125

[33] Tunlert A., Prasassarakich P., Poompradub S.: Antidegradation and reinforcement effects of phenyltrimethoxysilane- or $\mathrm{N}$-[3-(trimethoxysilyl)propyl]aniline-modified silica particles in natural rubber composites. Materials Chemistry and Physics, 173, 78-88 (2016). https://doi.org/10.1016/j.matchemphys.2016.01.041

[34] Wang X., Chen L., Guo Q.: Development of hybrid amine-functionalized MCM-41 sorbents for $\mathrm{CO}_{2}$ capture. Chemical Engineering Journal, 260, 573-581 (2015).

https://doi.org/10.1016/j.cej.2014.08.107 
[35] Keramati M., Ghoreyshi A. A.: Improving $\mathrm{CO}_{2}$ adsorption onto activated carbon through functionalization by chitosan and triethylenetetramine. Physica E: Low-dimensional Systems and Nanostructures, 57, 161-168 (2014).

https://doi.org/10.1016/j.physe.2013.10.024

[36] Liu Q., Shi J., Zheng S., Tao M., He Y., Shi Y.: Kinetics studies of $\mathrm{CO}_{2}$ adsorption/desorption on amine-functionalized multiwalled carbon nanotubes. Industrial and Engineering Chemistry Research, 53, 11677-11683 (2014).

https://doi.org/10.1021/ie502009n
[37] Gedde U. W.: Polymer physics. Kluwer, Amsterdam (1999).

[38] Geethamma V. G., Sampath V.: Rubber as an aid to teach thermodynamics: The discovery by a blind scientist. Resonance, 24, 217-238 (2019). https://doi.org/10.1007/s12045-019-0772-x 